\title{
Institutional stakeholders' perceptions of a sustainable neighbourhood in metropolitan Lagos
}

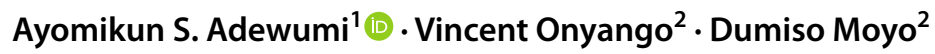

Received: 2 January 2021 / Accepted: 8 June 2021 / Published online: 6 July 2021

(c) The Author(s) 2021

\begin{abstract}
Understanding the term urban sustainability continues to dominate discourse in the built environment as societies explore how cities can be considered sustainable. Due to the increasing rate of urbanization, scholars argue that the battle for sustainability will be won or lost in cities; recognizing the crucial role that neighbourhoods can play as building blocks of urban areas. However, while the context-specificity of the several approaches to sustainability at the neighbourhood level has been recognised, no single accepted understanding of a sustainable neighbourhood has emerged. This paper explores institutional stakeholders' understanding of a sustainable neighbourhood using questionnaire data from metropolitan Lagos. This aligns with the critical realism philosophical stance which believes that knowledge can be sourced through the perception of people with respect to an underlying structure based on their reality. The findings show variations in the perceptions with institutions having similar responsibilities differing in their understanding of the concept. It was unclear why a single common understanding was missing and why certain elements were more emphasised than others even in institutions having similar roles. Further research should explore the mechanisms at play in influencing these understandings and how they may differ in various urban contexts in Sub-Sahara Africa.
\end{abstract}

Keywords Cities $\cdot$ Context-specificity $\cdot$ Perception $\cdot$ Stakeholders $\cdot$ Sustainable neighbourhood

Ayomikun S. Adewumi

adewuma5@1sbu.ac.uk

Vincent Onyango

v.onyango@dundee.ac.uk

Dumiso Moyo

d.moyo@dundee.ac.uk

1 Architecture Division, School of the Built Environment and Architecture, London South Bank University, London, UK

2 Architecture and Urban Planning, University of Dundee, Dundee DD1 4HN, UK 


\section{Introduction}

With sustainability as a recurring theme in the built environment discourse (AUC 2014; UNDESA 2016; UNHABITAT 2016), recent focus has been on cities, which accounts for about 55\% of the global population (UNDESA 2018) and soon to be $70 \%$. Also, the neighbourhood is increasingly being recognised as a crucial building block to the concept and delivery of the sustainable city (Ferwati et al. 2019; Wangel et al. 2016). It is noteworthy that planning at the neighbourhood level is not new. It is traceable to the works of pioneer urban planners. Famously, the Garden City concept transformed the profession of urban planning, postulating a neighbourhood relationship and spatial arrangement of urban activities. Developed by Ebenezer Howard, a British urban planner in the closing decades of the nineteenth century, it envisioned a mix of the best of the city and the countryside. It attempted to establish connections between the dwelling unit, the neighbourhood, the ward, and the town in relation with other places (Farr 2008). Later, the Neighbourhood Unit emerged as a safe and walkable space, providing specific guidelines for how residences, community services, streets and businesses should be spatially distributed. Developed by the American Clarence Perry, it served as a framework for urban planners attempting to design functional, self-contained, and desirable neighbourhoods in the early twentieth century in industrialising cities (Choguill 2008; Perry 1929). The Radburn concept was another notable turn to planning at the neighbourhood level, developed in 1929 by Clarence Stein and Henry Wright. Characterised by a superblock and a cul-de-sac, it promoted neighbourhoods with pedestrian paths that do not cross any major roads to encourage interaction among residents.

Recently, Neighbourhood Sustainability Assessment Frameworks (NSAFs) have emerged as tools to assess proposed neighbourhoods against an array of sustainability indicators (Wangel et al. 2016). They have been helpful and providing direction in the conceptualisation and approval of sustainable neighbourhoods in contexts where they have been applied (Cashmore and Kornov 2013; Berardi 2013). However, the problem has been that while these frameworks continue to gain prominence, their non-transferability from one context to another has been acknowledged (Fischer and Onyango 2012; Gazzola et al. 2011; Fischer and Gazzola 2006). Consequently, Yigitcanlar et al. (2015) and Dawodu et al. (2017) have canvassed for fit-for-purpose definition of the systems and indicators for assessing the sustainability credentials of urban neighbourhoods in developing countries.

To contribute to meeting this challenge which is to date relatively unaddressed in the wider urban sustainability discourse, this study explores what a sustainable neighbourhood is. This is within the perspective of institutions in Lagos as a benchmark knowledge of Sub-Saharan Africa (SSA) reality. Lagos offers a practical exemplar of a SSA urban context from which relevant data and lessons can be drawn, which would easily resonate with several similar SSA urban areas. Globally, Lagos is ranked 17th most populous city with around 19 million people (LASG 2016). With a population density of 5926 per square kilometre (Komolafe et al. 2014), Metropolitan Lagos has one of the fastest annual population increase 
of 275,000 persons per annum. The focus on institutions is crucial to the delivery of urban sustainability, as institutions serve the societal function of simplifying the actions and work of individuals (e.g., academics, practitioners and policymakers). Institutions provide a means to control society and people (e.g., via rules and guidelines; assigning roles upon which society and its agents can participate in maintaining order). This makes an understanding of the institutional perceptions important to delivering urban sustainability. The next section presents a theoretical context to this paper; Sect. 3 explains the methodology; Sect. 4 presents the results, and their implications are discussed in Sect. 5. The conclusions and recommendations are drawn in Sect. 6.

\section{Theoretical context}

\section{Neighbourhoods as building blocks for urban sustainability}

Some scholars argue that the neighbourhood scale has significant implication for urban sustainability (Dawodu et al. 2017; Ferwati et al. 2019; Moroke et al. 2019). This is premised on two main arguments. One, neighbourhoods are building blocks for urban areas (Wangel et al. 2016) and as a result, urban sustainability will be unattainable if its component parts are themselves unsustainable (Choguill 2008). Corroborating this view, Stanislav and Chin (2019) and Barton et al. (2010) submit that the overall quality of an urban area is determined by the quality of its neighbourhoods. Two, neighbourhoods offer appropriate platform to access the socio-economic impacts of developments, while facilitating citizens' involvement in decisionmaking (Moroke et al. 2019; Sharifi 2016). Therefore, neighbourhoods offer a unit of scale and function that could be used as a building block for planning sustainable urban places.

\section{The neighbourhood scale}

The term 'neighbourhood', although frequently used in the urban planning discourse (Choguill 2008), has no single agreed definition (Kearns and Parkinson 2001; Rohe 2009). For instance, is it a street of 100 people or a ward of 10,000 inhabitants? However, the neighbourhood scale of spatial development can be understood using Lefebvrian conception of the production of the space as elaborated by Salama and Wiedmann (2013) and Salama (2019) (Fig. 1). The "conceived space" perceives a neighbourhood as defined by the intellectual capacities of planners, engineers, and other built environment professionals, forming a basis and a guide for making decisions. For instance, based on the conceived space ideology, it is "a place with specific physical boundaries" (Keller 1968, p. 89; Golab 1982).

A neighbourhood as a "perceived space" is the immediate social and physical environment around the dwelling unit (Berk 2010): "a limited territory within a larger urban area, where people inhabit dwellings and interact socially" (Hallman 1984, p. 13). The "perceived space" is where movement and interaction occur, and 


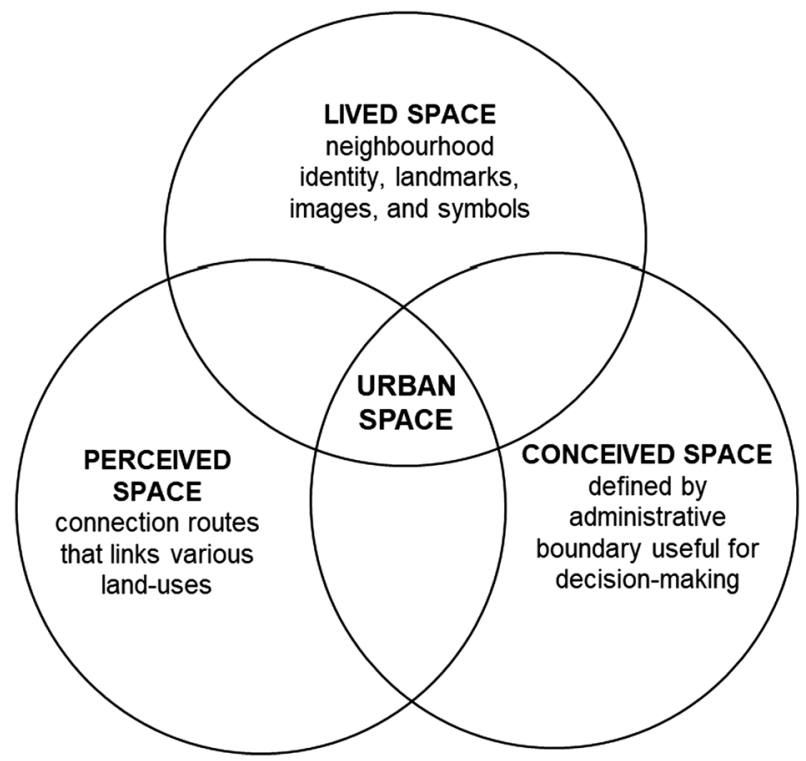

Fig. 1 The Lefebvrian triadic conception of space, made up of a confluence of three key understandings

networks are developed and materialised (Salama 2019). This understanding supports Young Foundation (2010) that perceived the neighbourhood scale based on the administrative structure of the area or authority. In some instances, an electoral ward, or part of it may be referred to as a neighbourhood. It explains the aspect of the neighbourhood that links places for work, leisure, and private life. The "lived space" refers to the public realm and its associated images and symbols: a non-verbal relationship of humans to space which are essentially subjective. Thus, a neighbourhood is defined by a variety of building uses and human activity with several places to go within walking distance.

Drawing from the conceived, perceived, and lived space perspectives, Wheeler (2013) and Bianca (2000) defined a neighbourhood as an area that can be traversed by foot with some distinct and unifying social, architectural, historical, and economic features. It is a residential area with a radius of about 400 to $600 \mathrm{~m}$ (ODPM 2004), of distinctive identity, often distinguished by name and bounded by recognisable barriers or transition areas such as railway lines, main roads, parks, and the age or character of buildings (Barton et al. 2010).

Whilst these definitions identified the distinctive character of a neighbourhood in terms of its spatial and administrative extents, including social interrelationships, a more detailed definition was given by Galster (2001, p. 2112): conceiving the neighbourhood as 'the bundle of spatially based attributes associated with clusters of residences, sometimes in conjunction with other land uses'. These attributes include:

(i) Structural characteristics of buildings e.g., type, materials and design;

(ii) Infrastructural characteristics e.g., roads, sidewalks and utility services;

(iii) Demographics e.g., age patterns, family composition and religious types; 
(iv) Sentimental characteristics e.g., residents' sense of identification with places;

(v) Class status e.g., income groups, occupation and education status;

(vi) Public amenities e.g., schools and recreation centres;

(vii) Environmental characteristics e.g., extent of land, air, water, and noise pollution;

(viii) Proximity characteristics e.g., nearness to major destinations;

(ix) Political characteristics e.g., local political networks;

(x) Social interactive characteristics e.g., local friends and kin networks.

These attributes help in understanding a neighbourhood using characteristics which may vary from context to context.

\section{A sustainable neighbourhood}

A sustainable neighbourhood has been defined by scholars from the perspectives of liveability, and intergenerational and intragenerational equities (Bahadure and Kotharkar 2018). Using the lens of liveability, it is a place "where people want to live, work, prosper and enjoy a good quality of life, now and in the future" (Roberts 2009, p. 128; CNU 2016). For intergenerational and intragenerational equities, a neighbourhood is considered sustainable if it meets the diverse needs of both existing and future residents, by contributing to high quality of life with opportunities and choices where all activities are executed within the earth's carrying capacity (ODPM 2004). However, this understanding can also be contested on the basis that, while we can know the needs of present generations, we do not know those of future generations. A sample of the various sustainability agendas from the international to the local levels suggests 10 key characteristics of a sustainable neighbourhood (Table 1).

Some understandings of a sustainable neighbourhood, from which we can decipher recurrent themes e.g., liveability and interdependent pillars are found in existing NSAFs (Table 2).

\section{Neighbourhood development in metropolitan Lagos}

Neighbourhoods in metropolitan Lagos can be discussed in terms of their spatial development as either master planned or piecemeal development. The master planned is a large-scale housing delivery either by the government or private institutions and can be either a single housing estate (where an individual or family occupies a detached dwelling) or mixed-housing estate (where a single building known as a 'block' by virtue of its design can accommodate more than one family). Referred to as "mass housing" by the National Housing Policy (Ocholi et al. 2015), the master planned development is a process of simultaneous production of large number of decent, safe, sanitary, and affordable residential buildings to meet the needs of the population and reflecting their socio-economic, cultural aspiration, and preferences. The master planned neighbourhood developments by government dominate the housing sector in metropolitan Lagos due to the active involvement of the government to reduce the housing deficit (Omolabi and Adebayo 2017). The master planned neighbourhood development by private 


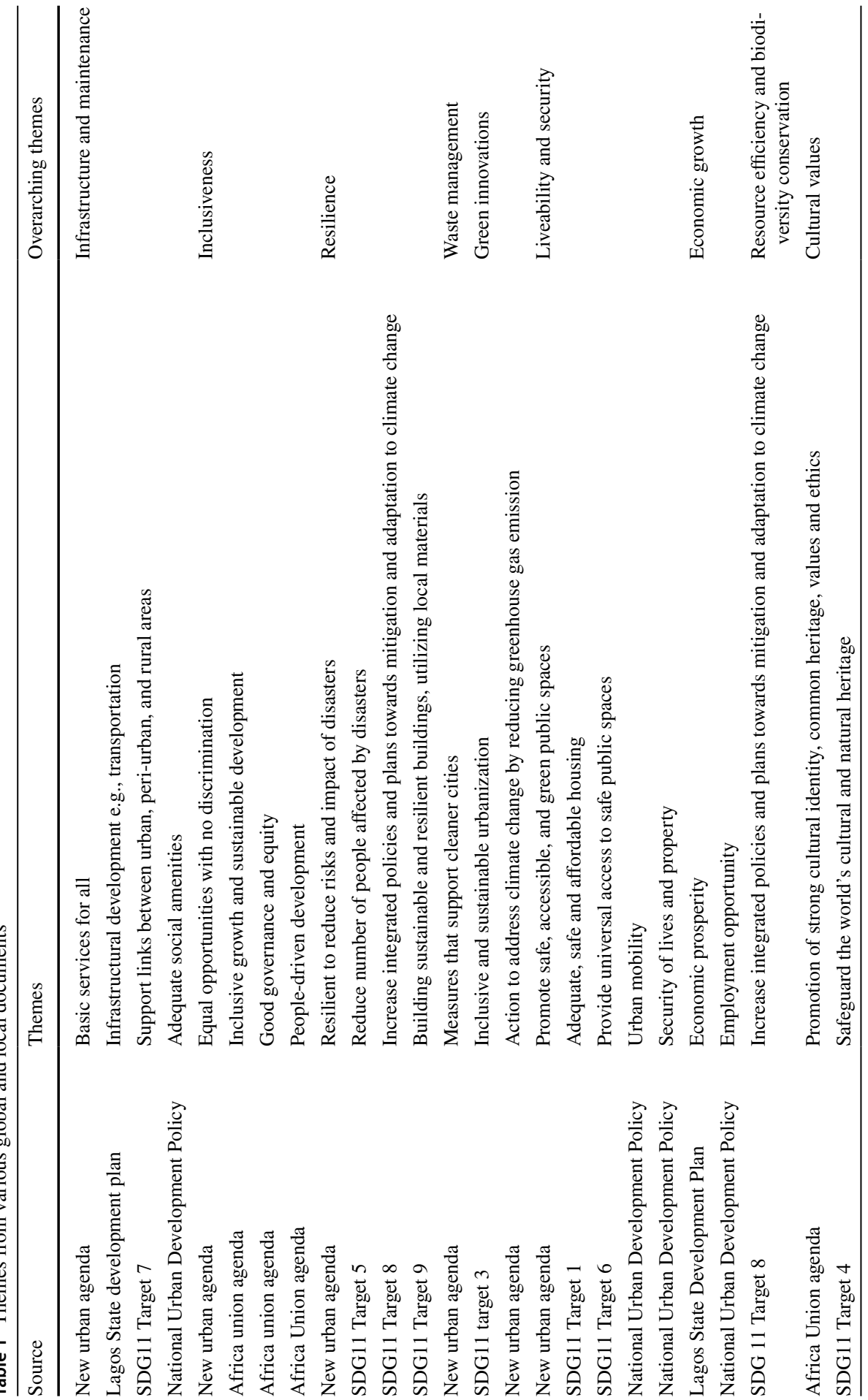




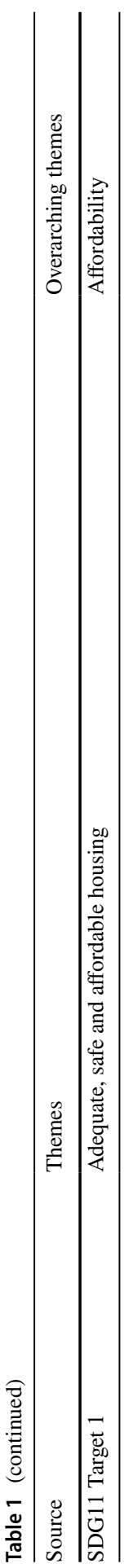


Table 2 Guiding visions and goals of some NSAFs

\begin{tabular}{ll}
\hline $\begin{array}{l}\text { Neighbourhood sustainability } \\
\text { assessment frameworks }\end{array}$ & Guiding vision and goals \\
\hline BREEAM Communities & $\begin{array}{r}\text { Places that people want to live and work in, are good for the environ- } \\
\text { ment and are economically successful } \\
\text { Enhance smart growth, new urbanism and green infrastructure and } \\
\text { buildings }\end{array}$ \\
PEED-ND & $\begin{array}{c}\text { Communities that improve quality of life through an integration of the } \\
\text { four pillars: environmental, economic, cultural and social }\end{array}$ \\
Green Star Communities & $\begin{array}{c}\text { Enhance liveability, local economic property, and delivery of sustain- } \\
\text { able outcomes }\end{array}$
\end{tabular}

institutions (Agbola et al. 2012) whilst seeking the maximum possible return on investment are mainly targeted to the medium and high-income group of the society.

A piecemeal neighbourhood development type is formed from individuals who build own houses. They are built in 'pieces' of single houses in the same area until they grow to form a neighbourhood. However, they are most times supported with basic amenities and facilities from government. In this arrangement, the layout is designed from which plots are sold to prospective buyers. The layout basically involves dividing the lots into blocks, and plots, indicating the land use pattern and access roads. This neighbourhood typology encourages a variety of designs from the prospective household owners unlike the master planned neighbourhood which is usually of a single design.

This study will focus on the master planned neighbourhood (housing estates) for two main reasons. Firstly, it is at this scale of planning, involving large areas and several users, that the principles of sustainable neighbourhoods can best be operationalised and assessed in terms of socio-cultural, economic, and environmental issues (Berardi 2013; Wangel et al. 2016). This is unlike the piecemeal development where planning and decision-making are only carried out at the single building scale with limited footprints in terms of area and users. Second, most housing schemes in metropolitan Lagos are executed at this typology of mixed housing estates as opposed to the piecemeal housing developed by individuals (Ibimilua and Ibitoye 2015; Jaiyeola 2012; Omolabi and Adebayo 2017) through its various institutions such as the Lagos State Development and Property Corporation (LSDPC), Ministry of Housing; and Lagos Building Investment Company amongst others. Therefore, empirical focus on this typology will be relevant based on its potential to contribute to a significant proportion of neighbourhoods within an institutional framework that can be amenable to NSAF application.

\section{Research methodology}

\section{Philosophy}

Capturing stakeholders' understanding of a sustainable neighbourhood can be challenging because of its subjective nature and the difficulty in locating, characterising and/or and quantifying it empirically. Therefore, this study adopted critical 
realism philosophical stance, which acknowledges an explanatory linkage that integrates people's understanding in relation to their context (Archer 2002; EasterbySmith et al. 2012; Fletcher 2017). People's perceptions are likely to be aligned with concerns, issues, and experienced realities in their context. In addition, if a global understanding exists, this is likely to be modulated within local perspectives, and only the extent that they are relevant to the local context. Therefore, epistemologically, critical realism will allow the context in metropolitan Lagos to be accounted for in understanding the perceptions indicated by the stakeholders.

\section{Approach and strategy}

A qualitative research approach will help seek the thematic patterns and trends indicated in the questionnaire surveys (Creswell 2014). Surveys are widely used for gathering data on narrow and well-defined topics (Check and Schutt 2011) because of their versatility, efficiency, and generalizability (Babbie 2010). This strategy is appropriate for this study because stakeholders' perceptions in metropolitan Lagos can be varied and widely distributed among various backgrounds within the city.

\section{Data collection and sampling}

Semi-structured questionnaires (DeVaus 2001; Denscombe 2007), administered face-to-face to the following three categories of institutional stakeholders in metropolitan Lagos, were used to collect qualitative data on perceptions of what a sustainable neighbourhood meant to them as an institution.

(i) Regulators, i.e., government institutions responsible for ensuring that neighbourhood development in metropolitan Lagos adhere to the physical planning regulations. The key institutions in this are the Ministry of Physical Planning and Urban Development; Lagos State Building Control Agency; Lagos State Physical Planning and Development Authority; and the New Town Development Authority.

(ii) Developers, i.e., private or government agencies responsible for delivering neighbourhoods. The key ones are Ministry of Housing; Lagos State Building Investment Company; and Lagos State Development and Property Corporation.

(iii) Built environment professionals, i.e., practitioners (in government ministries and agencies) and academia (whose research area is in urban neighbourhood sustainability).

Participants identified in the category of the 'regulators' and 'developers' were based on nomination by the each of the ministries and agencies, because they were to serve as a voice for their respective institutions. To achieve this, a letter was sent ahead to the institutions to make a nomination. These are organised ministry and agencies where a participant from each one is representative. In addition, two private real estate companies were contacted to make nominations. As a result, 4 and 
5 participants were identified in the categories of regulators, and developers respectively (Tables 3 and 5). Staff of government ministries and agencies in the category of the built environment professionals were identified through random and snowball sampling techniques. A participant in each of the ministries was picked randomly, who subsequently suggested other prospective participants who will be willing to participate in the survey (in what is known as snowball). The random sampling was conducted by assigning a number to each of the staffs in the ministries visited. These numbers were written on folded different sheets of papers depending on the number of staffs. The folded papers were then all gathered in a pool from which one paper was selected randomly (representing the staff to contact), with each of the papers having an equal chance of being picked. In the same approach, participants from the academia were identified using the random sampling from the pool of academics (who are also built environment professionals) who have written extensively on neighborhood planning in metropolitan Lagos. 12 participants were identified for this category (Table 5). This makes a total of 21 participants in all for the study.

\section{Data analysis}

Qualitative data from the questionnaires were analysed thematically. Braun and Clarke (2008, p. 79) defined thematic analysis as "a method of identifying, analysing, and reporting patterns (themes) within data" involving a "coding and categorising the patterns" in the data (Patton 2015; Leedy and Omrod 2001; Punch 2009). Thematic analysis helped to understand the various meanings of a sustainable neighbourhood and how they are distributed across the institutions. The NVivo software (QSR 2019) helped to organise and analyse the qualitative data faster and efficiently.

\section{Results}

The results are presented following the key categories of the institutions, to highlight what is similar and different among them.

\section{Regulators}

The respondents in this category had appreciable years of experience (Table 3), which underpinned the reliability of their responses.

Table 3 Years of experience of respondents

\begin{tabular}{lc}
\hline Regulatory institutions & $\begin{array}{r}\text { Years of } \\
\text { experience }\end{array}$ \\
\hline New Town development Authority (NTDA) & $6-10$ \\
Ministry of Physical Planning and Urban Development (MPPUD) & $11-20$ \\
Lagos State Building Control Agency (LABCA) & $11-20$ \\
Lagos State Physical Planning and development Authority (LASPPDA) & $11-20$ \\
\hline
\end{tabular}


Out of the 10 themes that emerged from the literature five (infrastructure and maintenance, liveability and security, economic growth, and resource efficiency and biodiversity conversation) were captured by the regulators' understanding of the concept of a sustainable neighbourhood. The rest (inclusiveness, resilience, waste management, green innovations, cultural values, and affordability) were not, reflecting a gap between the international literature and the Metropolitan Lagos. "Infrastructure and maintenance" and "liveability and security" had two entries (from LASPPDA and MPPUD) while the other three themes had single entries each: indicating a low frequency and, therefore, level of agreement in using these themes to describe a sustainable neighbourhood.

LABCA defined a sustainable neighbourhood using the Brundtland commission's perspective, under the two themes of "infrastructure and maintenance" and "resource efficiency and biodiversity conservation".

an estate developed to meet the needs of both present and future generations' users while considering and minimising the consumption and waste of energy

The understanding of the LASPPDA can be mapped under the two themes of "liveability and security" and "economic growth".

one that is liveable, workable, that supports environmental equity with catalyst for growth, urban regeneration, secured with economic enhancement

MPPUD also shared similar understanding with its subsidiary agency (LASPPDA) by explaining sustainable neighbourhood from the liveability perspective as one that is not overcrowded or congested.

one that can be attained in such a way that it can take the number of people or populace that is required

NTDA defined a sustainable neighbourhood as one that has a strategy to maintain its infrastructure and solve problems.

One that would have adequate management framework for routine turn around maintenance and other legislations that can address other urban development problems

The NVivo result showed clear variations in the themes underpinning the institutions' understandings of a sustainable neighbourhood (Fig. 2).

\section{Developers}

The respondents in this category had appreciable years of experience (Table 4), which underpinned the reliability of their responses.

Out of the 10 themes that emerged from literature (Table 1), the developers' understanding captured six, leaving out "green innovations", "inclusiveness", "waste management", and "liveability and security". "Affordability" and "infrastructure and maintenance" had the highest entries of two, while "cultural values" and "resource efficiency and biodiversity conservation" had one each. 

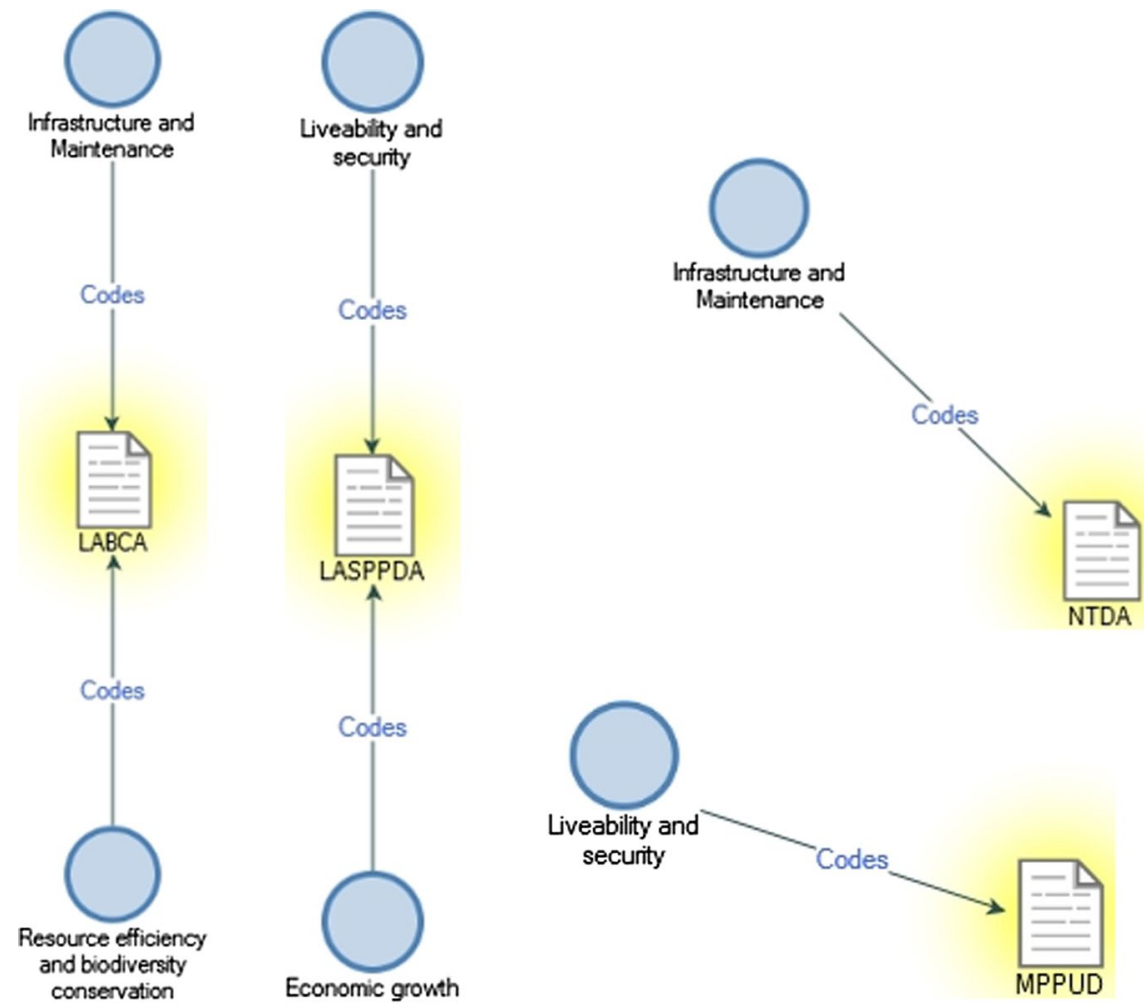

Fig. 2 The variation in regulators' understanding of a sustainable neighbourhood

$\mathrm{MoH}$ had a similar understanding of a sustainable neighbourhood with LASBCA and adopting the Brundtland Commission's definition of sustainability. The definition from LSDPC mapped under the two themes of "cultural values" and "economic growth".

a built environment with minimum negative impact on socio-cultural and economic activities

Table 4 Years of experience of respondents

\begin{tabular}{ll}
\hline Developer institutions & Years of experience \\
\hline Private Developer (PDEV1) & $6-10$ \\
$\begin{array}{l}\text { Lagos State Development and Property Corpo- } \\
\quad \text { ration (LSDPC) }\end{array}$ & $11-20$ \\
Lagos Building Investment Company (LBIC) & $11-20$ \\
Ministry of Housing (MoH) & Above 20 \\
Private Developer (PDEV2) & Above 20 \\
\hline
\end{tabular}



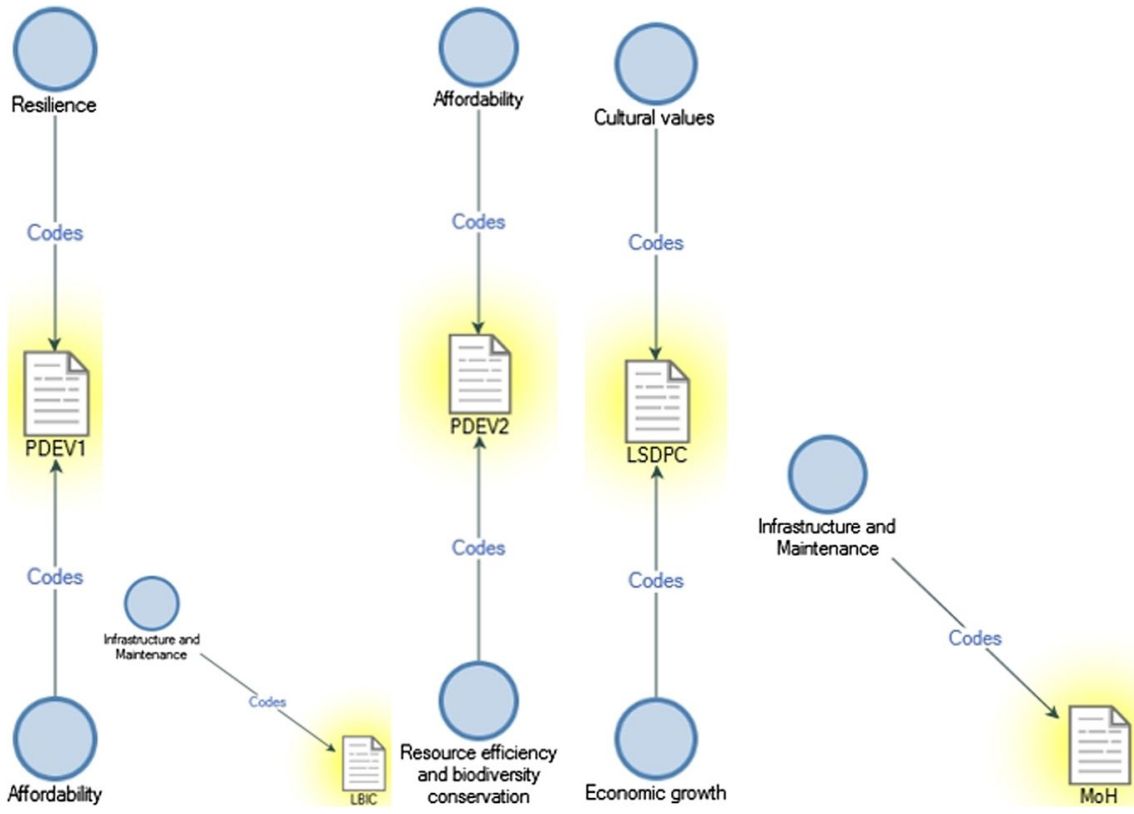

Fig. 3 The variation in developers' understanding of a sustainable neighbourhood

Table 5 Background information of built environment professionals from ministries and agencies

\begin{tabular}{|c|c|c|c|}
\hline Profession & Institutional affiliation & Anonymised name & Years of experience \\
\hline $\begin{array}{l}\text { Town Planner } \\
\text { Town Planner } \\
\text { Town Planner }\end{array}$ & $\begin{array}{l}\text { New Town Development Authority } \\
\quad(n=3)\end{array}$ & $\begin{array}{l}\text { NTDA2 } \\
\text { NTDA3 } \\
\text { NTDA4 }\end{array}$ & $6-10$ \\
\hline Builder & $\begin{array}{l}\text { Ministry of Housing } \\
\text { Architecture and Building Services sec- } \\
\text { tion }(n=1)\end{array}$ & MoH ABS2 & $11-20$ \\
\hline $\begin{array}{l}\text { Civil Engineer } \\
\text { Civil Engineer }\end{array}$ & Engineering section $(n=2)$ & $\begin{array}{l}\text { MoH ENG1 } \\
\text { MoH ENG2 }\end{array}$ & $11-20$ \\
\hline $\begin{array}{l}\text { Quantity Surveyor } \\
\text { Town Planner }\end{array}$ & $\begin{array}{l}\text { Quantity Surveying section }(n=1) \\
\text { Lagos State Building Control Agency } \\
\quad(n=2)\end{array}$ & $\begin{array}{l}\text { MOH QS1 } \\
\text { LABCA1 } \\
\text { LABCA3 }\end{array}$ & $6-10$ \\
\hline $\begin{array}{l}\text { Architect/Academia } \\
\text { Architect/Academia } \\
\text { Architect/Academia }\end{array}$ & $\begin{array}{l}\text { Obafemi Awolowo University, Nigeria } \\
(n=2) \\
\text { University of New South Wales, Aus- } \\
\text { tralia }(n=1)\end{array}$ & $\begin{array}{l}\text { ACAD1 } \\
\text { ACAD2 } \\
\text { ACAD3 }\end{array}$ & Above 20 \\
\hline
\end{tabular}


The LBIC had a similar understanding with the NTDA: that a proper management framework is what makes a neighbourhood sustainable.

an estate that is not abandoned, where proper management is available

In contrast, the understanding by of one of the private developers (PDEV1) can be mapped under the two themes of "affordability" and "resilience": i.e., "affordable housing that can stand the test of time". Another private developer (PDEV2) shared similar views, submitting that the sustainability of a neighbourhood anchors on the two themes of "affordability" and "resource efficiency and biodiversity conservation". Figure 3 summarises clear variations in the developers' understandings of a sustainable neighbourhood.

\section{Built environment professionals}

Table 5 presents the background information of professionals from the various institutions responsible for neighbourhood development and regulation in metropolitan Lagos.

The built environment professionals' understandings captured 7 out of the 10 themes from literature: excluding "green innovations", "cultural values", and "resilience". However, a new theme emerged which has to do with "compliance with planning regulations". Their understandings emphasised "infrastructure and maintenance", with 9 entries; followed by "liveability and security" with 5; and themes like "economic growth", "inclusiveness", and "waste management" having one each.

NTDA2 understood a sustainable neighbourhood from the perception of the Brundtland's commission as one that meets the needs of future generation with basic infrastructure.

a neighbourhood can be considered sustainable if future generation can benefit some quality of housing and its supporting facilities without hindrance

MoH ABS2 defined a sustainable neighbourhood as that which meets the need of only present generation with consideration for environmental integrity.

a neighbourhood that meets the needs of the present without compromising the integrity of the environment

ACAD2 defined it as that which meets both present and future needs, albeit focusing on infrastructure and amenities.

a neighbourhood that is planned to meet the present or current needs of the occupants and also provides opportunities for all envisaged future needs and requirements - in terms of basic infrastructural facilities and such other housing needs

Although from the same agency with NTDA2, the definition presented by NTDA3 can be mapped under the three themes of "infrastructure and maintenance", "resource efficiency and biodiversity conservation", and "liveability and security". 
a self-sustaining place that has all basic form of complimentary uses. It is one that makes effective use of available resources to maximally create quality, liveable, working, and light commercial based area for living

NTDA4 shared similar understanding with NTDA3 but went further to include to affordability as a key theme that defines a sustainable neighbourhood in addition to "infrastructure", resource efficiency and biodiversity conservation", and "affordability".

a well-planned area of land with buildings and functional infrastructure, economically, and environmentally designed to produce shelter for all levels of income earners

ACAD1; MoH ENG1; and MoH ENG2 shared similar understanding as their definition can be mapped under "infrastructure" except for ACAD1 which included "liveability and security" and MoH ENG1 that extended the definition to "waste management".

ACAD1- a well-thought-out layout made up of building units which are well serviced and capable of provisioning secured habitable environment for human comfort

MoH ENG1- a well laid out area with good road network and such infrastructural facilities as power, water, central sewage and recreational area

MoH ENG2- one that has a regular power and water supply

MoH QS1 defined a sustainable neighbourhood as that which is "affordable" and "liveable".

MoH QS1- one that is affordable and habitable for living

With a different understanding and perception, LABCA1 and LABCA3 both emphasised that a neighbourhood is considered sustainable when it follows physical planning regulations. Besides, LABCA1 added liveability.

LABCA1- an environment that is liveable, habitable and comply with planning regulations

ACAD3- a neighbourhood with good environmental quality, access to local economic opportunities, affordable services and amenities and with sense of community, cultural identity and belonging

The mapping of the results with the 10 overarching themes that emerged from the literature showed variation in their understandings of a sustainable neighbourhood (Fig. 4).

Overall, the results showed variations in the institutional stakeholders' understandings of the sustainable neighbourhood concept. Even institutions that performed the same function had contrasting views while some that perform different functions shared similar perceptions and understanding of the concept. Amongst the 10 themes and the new one that emerged i.e., "infrastructure and maintenance", "liveability" and "affordability" dominated across the categories of institutional stakeholders (Fig. 5). 


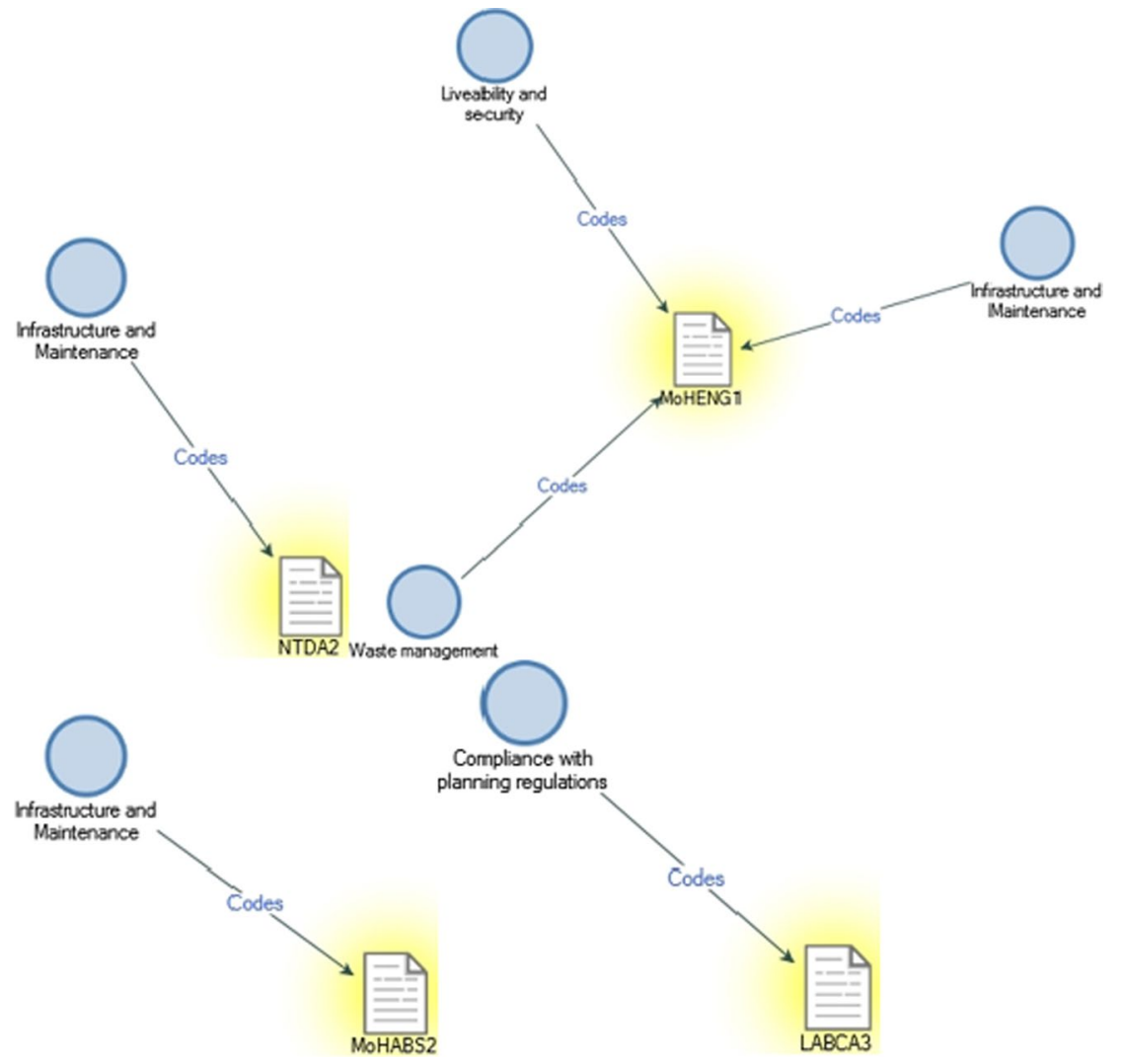

Fig. 4 The variation in selected built environment professionals' understanding of a sustainable neighbourhood

Table 6 summarises the thematic distribution of the stakeholders' understanding of a sustainable neighbourhood, with themes such as green innovations, inclusiveness, waste management, resilience, and cultural values, excluded by two of the institutional categories.

\section{Discussion}

This section is structured following key implications of the results.

\section{Complexity in stakeholders' understandings}

The findings reveal both a diversity and variations in stakeholders' understanding of the sustainable neighbourhood concept which brings complexity and challenges to the decision-making process in planning for a sustainable neighbourhood. This 


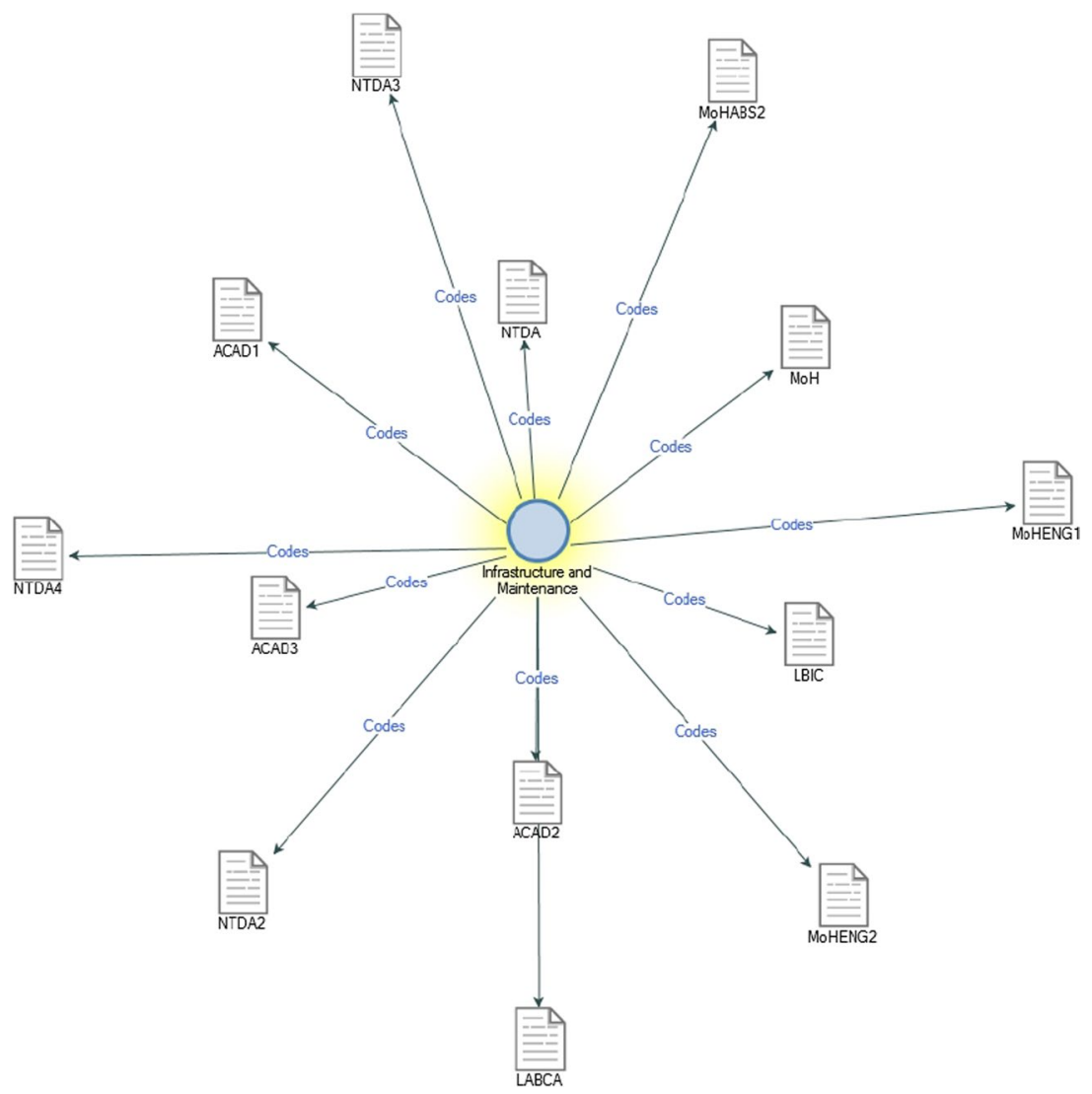

Fig. 5 The dominance of the infrastructure and maintenance theme in institutional stakeholders' perceptions

echoes existing literature (Edwards 2014; UN-Habitat 2015; Barton et al. 2010; and Blum and Grant 2006), highlighting the complexity in defining a sustainable neighbourhood. For example, ODPM (2004) posited that sustainability at the neighbourhood level should address issues of good governance; transport and connectivity; services; environmental; economy; housing and built environment. However, in practice, how are these pluralistic perceptions to be captured and addressed? Fundamentally, whose understanding is predominant and under what circumstances and why?

In terms of implications, this complexity further grounds the need for a robust collaborative and inclusive approach (Pope et al. 2005), with effective engagement with all stakeholders to ensure that their views, values, and aspirations are justifiably captured. This can create an avenue for social learning and more awareness on the various understandings and stakeholders' interests, about the concept of a sustainable neighbourhood. 


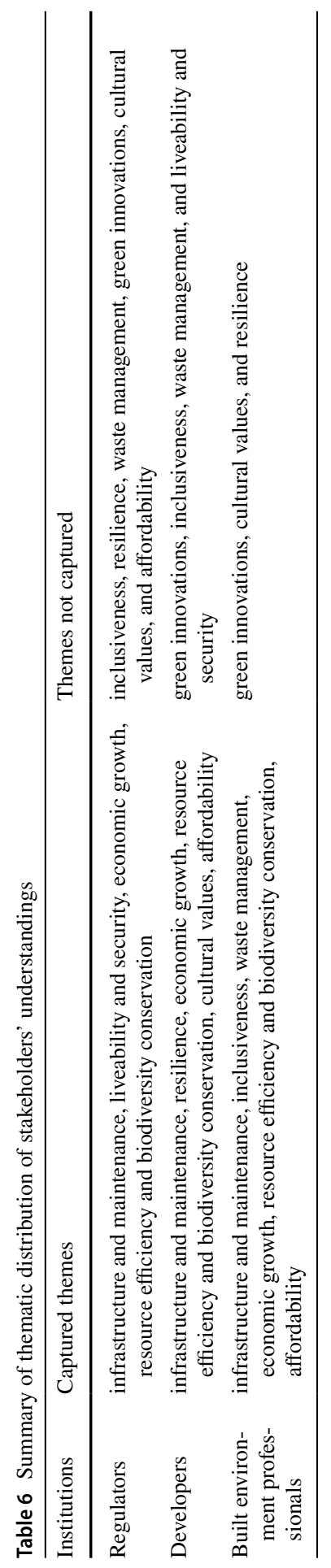




\section{Dominant themes}

Despite the various indicated understandings, some dominant themes emerged in the stakeholders' perceptions of a sustainable neighbourhood: "infrastructure and maintenance", "liveability", and "affordability". These themes are echoed in some NSAFs (BRE 2017; GBCA 2012; USGBC 2018; and AUPC 2010). For instance, the BREEAM communities has a focus on ensuring a neighbourhood that is liveable (BRE 2017); The Pearl Community Rating System has a category in its indicator set called "liveable communities" which is $22 \%$ of its total weight. These mirror recent advocacy for places that are liveable and promote citizens' well-being. Science for Environment Policy (2015) and Bell and Morse (2008) further elaborated on the centrality of these themes, positing that conceptualising sustainability at the neighbourhood level transcends addressing the concern of whether man is living within environmental limits, but also whether a good quality of life is enhanced. It involves delivering places where people can live, work, and enjoy good quality of living (Gehl 2010; Gehl and Svarre 2013; Wheeler 2013; Schneekloth and Shibley 1995). This is further reinforced in concepts like 'place-making', which call for creating healthy places for people (Parlemo and Ponzini 2015; Arefi 2014). The concern for affordability highlights the value of local context and reality, as affordability is a major concern in metropolitan Lagos. Low- and middle-income earners can hardly have access to affordable housing (Mbali and Okoli 2002; Hamiduddin 2015) which has led to development of slums and informal settlements in some parts of metropolitan Lagos (Pepple 2012).

Unsurprisingly, the findings also show that some of the themes captured in the international literature were only partially reflected in the perceptions of the various categories of stakeholders. For example, "inclusiveness" and "cultural values" only emerged in the built environment professionals and developers, respectively. None of the stakeholders' understanding captured "green innovations": perhaps a reflection of the relative ranking of the issue among other competing ones.

\section{Insight from critical realism}

Critical realism has been useful in explaining the link between the indicated stakeholders' understanding of a sustainable neighbourhood and their lived realities. This is reflected in the three dominant themes of "infrastructure and maintenance", "liveability", and "affordability", reflecting day-to-day concerns about a neighbourhood in metropolitan Lagos, emerging as prominent. These realities predominated institutional stakeholders' perceptions of a sustainable neighbourhood, even though it was evident that they were well-educated, likely to be welltravelled and aware of the broader international discourse about urban sustainability. Even where the 'internationalised and widely acknowledged' Brundtland definition taking centre stage, rather, stakeholders' understandings of local needs, values, and aspirations in Lagos, still emerged as predominant. This was clear evidence of how the understanding of a sustainable neighbourhood, even when 
embedded within the globalised context, was nevertheless constrained by, and interpreted from issues driven by the local context in Metropolitan Lagos.

\section{Conclusion}

This study concludes that various institutions in Metropolitan Lagos shared some common understandings as well as differences about what can be considered as a sustainable neighbourhood. Although elements of the more globally acknowledged Brundtland definition of sustainability was evident, most of the indicated understandings were influenced by realities in their more local contexts. The institutions indicated that their understanding transcended addressing challenges like climate change, biodiversity loss, pollution, and land and water degradation, to extend to such components like liveability, security, provision of amenities and infrastructure, and economic prosperity, which appeared to be more driven by local concerns. Furthermore, it is noteworthy that institutions having similar responsibilities significantly differed in their understanding of the concept. There were clear attempts to give attention to the global concepts on the one hand, while on the other hand constrained by local realities and aspirations which are different from the more global ones. This findings imply that for those considering developing Neighbourhood Sustainability Assessment Framework in a subSahara African context, they must pay attention to, and carefully address how the definitions and their indicators can be operationalised.

Generalisability of the findings is limited to the idea that the understandings in an urban setting in SSA will be found to have its own set of similar and different elements from the Lagos case study and the international literature. While agreeing that the understanding of sustainability can be context specific, it remains unclear why certain elements are more emphasized than others, even in institutions having similar roles. It also remains a question reason a single common understanding of what a sustainable neighbourhood is missing or appears unreachable. Further research can explore the mechanism at play in influencing these perceptions and how they may differ in various sub-Sahara Africa cities and why.

Funding The authors did not receive support from any organisation for the submitted work.

Data availability Data sharing not applicable to this article as no datasets were generated or analysed during the current study.

\section{Declarations}

Conflict of interest The authors have no conflicts of interest to declare that are relevant to the content of this article.

Open Access This article is licensed under a Creative Commons Attribution 4.0 International License, which permits use, sharing, adaptation, distribution and reproduction in any medium or format, as long as 
you give appropriate credit to the original author(s) and the source, provide a link to the Creative Commons licence, and indicate if changes were made. The images or other third party material in this article are included in the article's Creative Commons licence, unless indicated otherwise in a credit line to the material. If material is not included in the article's Creative Commons licence and your intended use is not permitted by statutory regulation or exceeds the permitted use, you will need to obtain permission directly from the copyright holder. To view a copy of this licence, visit http://creativecommons.org/licen ses/by/4.0/.

\section{References}

Agbola T, Kasim F, Adesanya A, Emmanuel A, Olujimi J, Ogunleye M (2012) Issues and challenges of urban and regional planning in Nigeria. In: State of planning report. The Nigerian Institute of Town Planners, Abuja

Archer R (2002) Education policy and realist social theory. Routledge, London

Arefi M (2014) Deconstructing placemaking. Routledge, Oxon

AUC (2014) Agenda 2063: the Africa we want. Africa Union Commission, Addis Ababa

AUPC (2010) The pearl rating system for Estidama. Abu Dhabi Urban Planning Council, Abu Dhabi

Babbie ER (2010) The practice of social research, 5th edn. Wadsworth Cengage Learning, Belmont

Bahadure S, Kotharkar R (2018) Framework for measuring sustainability of neighbourhoods in Nagpur, India. Build Environ 127:86-97. https://doi.org/10.1016/j.buildenv.2017.10.034

Barton H, Grant M, Guise R (2010) Shaping Neighbourhoods for local health and global sustainability, 2nd edn. Routledge, London

Bell S, Morse S (2008) Sustainability indicators- measuring the immeasurable? 2nd ed. Earthscan, London

Berardi U (2013) Sustainability assessment of urban communities through rating systems. Environ Dev Sustain. https://doi.org/10.1007/s10668-013-9462-0

Berk M (2010) The concept of neighbourhood in contemporary residential environments: an investigation of occupants' perception. Delft University of Technology, Delft

Bianca S (2000) Urban form in the Arab world, past and present. Thames and Hudson, London

Blum A, Grant M (2006) Sustainable neighbourhoods: Assessment tools for renovation and development. J Int Res Publ 1:35-52

Braun V, Clarke V (2008) Using thematic analysis. Qual Res Psychol 3(2):77-101

BRE (2017) BREEAM communities: technical manual SD202-1.2-2012. Building Research Establishment, Watford

Cashmore M, Kornov L (2013) The changing theory of impact assessment. In: Bond A, Morrison-Saunders A, Howitt R (eds) Sustainability assessment: pluralism, practice, and progress. Routledge, London, pp 18-33

Check J, Schutt R (2011) Research methods in education. SAGE, Boston

Choguill C (2008) Developing sustainable neighbourhoods. Habitat Int 32:41-48

CNU (2016) Charter of the new urbanism. http://www.cnu.org/who-we-are/charter-new-urbanism

Creswell J (2014) Research design: qualitative, quantitative, and mixed methods approaches. SAGE, London

Dawodu A, Akinwolemiwa B, Chesmehzangi A (2017) A conceptual re-visualization of the adoption and utilization of the Pillars of sustainability in the development of neighbourhood sustainability assessment tools. Sustain Urban Areas 28:398-410

Denscombe M (2007) The good research guide. Open University Press, Berkshire

DeVaus D (2001) Research design in social research, 2nd edn. SAGE, London

Easterby-Smith M, Thorpe R, Jackson P (2012) Management research. SAGE, London

Edwards B (2014) Rough guide to sustainability: a design primer, 4th edn. RIBA Publications, London

Farr D (2008) Sustainable urbanism: urban design with nature. Wiley, New Jersey

Ferwati M, Al Saeed M, Shafaghat A, Keyvanfar A (2019) Qatar Sustainability Assessment System (QSAS)-Neighbourhood Development (ND) Assessment Model: coupling green urban planning and green building design. J Build Eng 22:171-180

Fischer TB, Gazzola P (2006) SEA effectiveness criteria-equally valid in all countries? The case of Italy. Environ Impact Assess Rev 26(4):396-409 
Fischer TB, Onyango V (2012) Strategic environmental assessment-related research projects and journal articles: an overview of the past 20 years. Impact Assess Project Appraisal 30(4):253-263. https:// doi.org/10.1080/14615517.2012.740953

Fletcher AJ (2017) Applying critical realism in qualitative research: methodology meets method. Int J Soc Res Methodol 20(2):181-194

Galster G (2001) On the nature of neighbourhood. Urban Stud 38(12):2111-2124. https://doi.org/10. 1080/00420980120087072

Gazzola P, Jha-Thakur U, Kidd S, Peel D, Fischer T (2011) Enhancing environmental appraisal effectiveness: towards an understanding of internal context conditions on organisational learning. Plan Theory Pract 12(2):183-204. https://doi.org/10.1080/14649357.2011.581008

GBCA (2012) Green Star communities: guide for local government. Green Building Council Australia, Melbourne

Gehl J (2010) Cities for people. Island Press, Washington

Gehl J, Svarre B (2013) How to study public life. Island Press, Washington

Golab C (1982) The geography of the neighbourhood. In: Bayer R (ed) Neighbourhoods in urban America. Kennikat Press, Port Washington, pp 70-85

Hallman H (1984) Neighbourhoods: their place in urban life. Sage, CA

Hamiduddin I (2015) Social sustainability, residential design and demographic balance: neighbourhood planning strategies in Freiburg, Germany. Town Plan Rev 86(1):29-52. https://doi.org/10.3828/tpr. 2015.3

Ibimilua AF, Ibitoye OA (2015) Housing Policy in Nigeria: an overview. Am Int J Contemp Res 5(2):53-59

Jaiyeola BE (2012) Housing quality to the low-income housing producers in Ogbere Ibadan. Nigeria Soc Behav Sci 35:483-494. https://doi.org/10.1016/j.sbspro.2012.02.114

Kearns A, Parkinson M (2001) The significance of neighbourhood. Urban Stud 38(12):2103-2110

Keller S (1968) The urban neighbourhood. Random House, New York

Komolafe A, Adegboyega S, Anifowose A, Akinluyi F, Awoniran D (2014) Air pollution and climate change in Lagos, Nigeria: needs for proactive approaches to risk management and adaptation. Am J Environ Sci 10(4):412-423

LASG (2016) Digest of Statistics 2016. Lagos Bureau of Statistics Ministry of Economic Planning and Budget, Ikeja

Leedy P, Omrod J (2001) Practical research: planning and design, 7th edn. Thousands Oaks, San Francisco

Mbali I, Okoli OG (2002) Affordable housing for low-income group in Nigeria. A rendefinition of the basic parameters. Housing Today 1(5):16-17

Moroke T, Schoeman C, Schoeman I (2019) Developing a neighbourhood sustainability assessment model: an approach to sustainable urban development. Sustain Urban Areas. https://doi.org/10. 1016/j.scs.2019.101433

Ocholi S, Manase D, Lowe J, Sommerville J (2015) Critical review of Nigeria National Housing Policies Delivery (NNHPD). Int J Eng Res Technol 4(9):718-724

Office of the Deputy Prime Minister, ODPM (2004) The Egan review: skills for sustainable communities. RIBA Enterprises Ltd, London

Omolabi AO, Adebayo PW (2017) An assessment of the housing policy performance towards public lowincome housing provision and management in Lagos, Nigeria. Int J Dev Sustain 6(8):792-809

Parlemo P, Ponzini D (2015) Place-making and urban development: new challenges for contemporary planning and design. Routledge, Oxon

Patton MQ (2015) Qualitative research and evaluation methods, 4th edn. SAGE, London

Pepple A (2012) Nigeria progress on improving the lives of slum-dwellers over the decade: a paper presented at the UNHABITAT International conference 26th-29th November 2012. In: NHABITAT international conference, Morocco

Perry CA (1929) The neighbourhood unit: a scheme of arrangement for the family-life community regional plan of New York and its environs. Arno Press, New York

Pope J, Morrison-Saunders A, Annadale D (2005) Applying sustainability assessment models. Impact Assess Project Appraisal 23(4):293-302. https://doi.org/10.3152/147154605781765436

Punch KF (2009) Introduction to research methods in education. SAGE, London

QSR (2019) NVIVO: unlock insights from your research. https://www.qsrinternational.com/nvivo/nvivoproducts. Accessed 15 Oct 2019 
Roberts P (2009) Sustainable communities. In: Cooper I, Symes M (eds) Sustainable urban development-changing professional practice. Routledge, Oxon, pp 127-144

Rohe W (2009) From local to global: one hundred years of neighbourhood planning. J Am Plan Assoc 75(2):209-230. https://doi.org/10.1080/01944360902751077

Salama AM (2019) Integrationist triadic agendas for city research: cases from recent urban studies. J Archit Urban 43(2):148-157. https://doi.org/10.3846/jau.2019.11220

Salama A, Wiedmann F (2013) Demystifying Doha: on architecture and urbanism of an emerging city. Routledge, London

Schneekloth L, Shibley R (1995) Placemaking: the art and practice of building communities. Wiley, New York

Science for Environment Policy, SEP (2015) In-depth report: indicators for sustainable cities. European Commision DG Environment by the Science Communication Unit, UWE, Bristol

Sharifi A (2016) From Garden city to eco-urbanism: the quest for sustainable neighbourhood development. Sustain Urban Areas 20:1-16. https://doi.org/10.1016/j.scs.2015.09.002

Stanislav A, Chin JK (2019) Evaluating livability and perceived values of sustainable neighbourhod design: new urbanism and original urban suburbs. Sustain Urban Areas. https://doi.org/10.1016/j. scs.2019.101517

UNDESA (2016) The world's cities in 2016. United Nations Department for Economic and Social Affairs, Kenya

UNDESA (2018) World urbanisation prospects. United Nations, New York

UN-Habitat (2015) A new strategy of sustainable neighbourhood planning. United Nations Human Settlements Programme (UN-HABITAT), Nairobi

UN-Habitat (2016) Urbanisation and development: emerging futures—world cities report 2016. United Nations Human Settlements Programme (UN-HABITAT), Nairobi

USGBC (2018) LEED ND V4 for neighbourhood development. US Green Building Council, Washington Wangel J, Wallhagen M, Malmqvist T, Finnveden G (2016) Certification systems for sustainable neighbourhoods: what do they really certify? Environ Impact Assess Rev 56:200-2013

Wheeler S (2013) Planning for sustainability: creating livable, equitable and ecological communities, 2nd edn. Routledge, Oxon

Yigitcanlar T, Kamruuzaman M, Teriman S (2015) Neighbourhood sustainability assessment: evaluating residential development sustainability in a developing country context. Sustainability 7:2570-2602

Young Foundation (2010, August) How can neighbourhoods be understood and defined? The Young Foundation. https://youngfoundation.org/wp-content/uploads/2012/11/How-can-neighbourhoodsbe-understood-and-defined-August-2010.pdf. Accessed 19 July 2019 